\title{
Converting the Wetlands, Engendering the Environment: The Intersection of Gender with Agrarian Change in The Gambia
}

\author{
Judith Carney \\ 1993. Economic Geography 69 (4), 329-348. ${ }^{1}$
}

The pace of environmental change in Third World during recent decades has directed increasing attention in regional studies to political ecology, a research framework that focuses on the socioeconomic hierarchies and power relations regulating land use and management (Blaikie and Brookfield, 1987; Bassett, 1988; Zimmerer, 1991; Bryant, 1992). However, the political ecology perspective is most frequently employed in the context of common property regimes in the Third World to refute Hardin's (1968) "free-rider" assertion, which attributes environmental degradation to unchecked use of common property resources. Challenges to Hardin's arguments have, as a consequence, overemphasized analysis of land in political ecological analysis to the exclusion of other important factors. In this paper, I argue that the relationship of common property rights to Third World environmental change may be better understood by adequately conceptualizing labor.

Population growth and consequent pressure on limited land is frequently invoked to explain how common property resources result in environmental change. But the accelerating incorporation of Third World environmental resources into the global economy, particularly evident in recent decades, suggests a different view, in that environmental transformations initiate patterns of income generation by placing new value on land-based resources, which in turn trigger changes in common property resources. The result is often a shift to centralized resource control without a

\footnotetext{
${ }^{1}$ Reprinted from the journal Economic Geography with permission from Clark University and Judith Carney.
} 
concomitant tendency toward privatization of land (Berry, 1989). Scarcity of land may be artificially created to gain control over labor for accumulation strategies that differentially benefit members within households.

I examine forms of environmental change on the wetlands of The Gambia during the past 25 years. Irrigation schemes play a central role in government policies aimed at diversifying agricultural exports while improving self-sufficiency in food grains. But the intensification of household labor regimes to year-round cultivation is inducing unparalleled gender conflict as communities reorient the common property regime to the new economic emphasis on irrigated production.

An examination of contemporary changes in the Gambian wetlands illuminates the interplay of environmental transformation, accumulation strategies, and women's work to changing common property regimes. In the Gambian system land is managed for individual use but is not individually owned. A number of users enjoy independent rights of usage, which is to say, individual rights to the benefits of his or her labor. Community land access is regulated by households with rights to exclude nonmembers of that collectivity. This political ecological analysis, which examines labor and rights of access to environmental resources, draws attention to the relationship of Gambian women's protests against the changing forms of control exercised over community property systems in the wetlands.

I use multiple case studies of two forms of wetland conversion: irrigated rice schemes and horticultural projects. Both forms of swamp development began in the colonial period when British officials sought to diversify exports from peanuts, the dominant cash crop, and improve domestic rice self-reliance. The projects failed to break down the gender division of labor in rice and vegetables, traditionally cultivated by women. Only in the post-independence period, with successful implementation of irrigation projects, did men labor with their wives in rice cultivation. But male participation also heralded an increasing control over surplus production and, frequently, female land dispossession. Nongovernmental organizations responded to women's declining economic opportunities in rice cultivation schemes by promoting irrigated horticultural projects among village women's groups. Horticultural projects have improved rural women's incomes but, like rice schemes, are rife with genderbased conflicts over access to irrigated land. Tracing the trajectories of the forms of irrigated development consequently reveals a process of land enclosure within the community property system which permits women's land access as laborers but denies full claims to the benefits produced.

In drawing attention to the labor rights that mediate the community property system, this paper makes two points. First, new patterns of income generation within community property regimes frequently result in a redefinition of rules of access to, and control over, benefits within the household and community. Second, this redefinition is contested by women and given political expression in their growing militancy and nascent social movements. Such "struggles over meaning" in community 
property regimes may provide a critical perspective for examining Third World women's growing militancy over environmental and economic change.

Building upon previous research in several Gambian wetland communities, the paper is divided into five sections. The first presents the environmental context of the Gambian wetlands, the extent and significance of wetland farming, as well as women's labor in ensuring its productive use. The next two sections provide a historical overview of the environmental and economic changes that modify women's access to, and use of, wetland resources, as well as recent policy shifts that address the country's environmental and economic crisis. Two case studies then detail the relationship between economic change and the process of land concentration and women's resistance. The paper concludes by analyzing how wetland commodification has made women's access to resources increasingly tenuous despite income gains.

\section{The Environmental Context of the Gambian Wetlands}

The Gambia, a narrow land strip 24-50 kilometers (14-30 miles) wide and nearly 500 kilometers (300 miles) long, encloses a low-lying river basin that grades gradually into a plateau, where the altitude seldom exceeds 100 meters (325 feet) (Fig. 1). The plateau forms about one-third of the country's land base and depends upon rainfall for farming (Carney, 1986, 21). Precipitation during the months of June to October averages 800-1,100 millimeters (31-43 inches) and favors the cultivation of millet, sorghum, maize, and peanuts. As in neighboring Sahelian countries, the Gambian rainfall regime fluctuates considerably between years and within a season. From the 1940s to 1980s, for example, annual rainfall declined by 15 to 20 percent and became increasingly distributed in a bimodal seasonal pattern (Hutchinson, 1983, 7) ${ }^{2}$. The recurrence of a two-week, midseason dry spell during the month of August increases cropping vulnerability on the uplands and dependence on lowland farming (Carney, 1986, 25-30).

The lowlands are critical for understanding human livelihood and survival in the unstable rainfall setting of the West African Sudano-Sahelian zone. Lowland environments permit a multiple land use cropping strategy that utilizes other forms of water availability, thereby freeing agricultural production from strict dependence on rainfall. Constituting nearly 70 percent of the country's land mass, the Gambian lowlands make available two additional environments for agriculture: (1) the alluvial plain flooded by the river and its tributaries; and (2) a variety of inland swamps that

${ }^{2}$ The drier climate cycle within the Sahel during the 1960s through the 1980s does not support the contention of long-term climatic change. Satellite measurements over the last decade reveal that the spread of the Sahara is not as widespread or severe as previously thought by the United Nations and other development organizations. The fluctuating precipitation regime is typical of climatic oscillations within the region over the long run ("Satellites expose myth of marching Sahara," 1991, 38). 
receive water from high water tables, artesian springs, or occasional tidal flooding (Carney, 1986, 20-21) (Fig. 2). The lowlands, which enable an extension of crop production into the dry season or even year-round, are planted to rice, although vegetables are frequently grown with residual moisture following the rice harvest (Dunsmore, 1976, 208-11; Carney, 1986, 82).
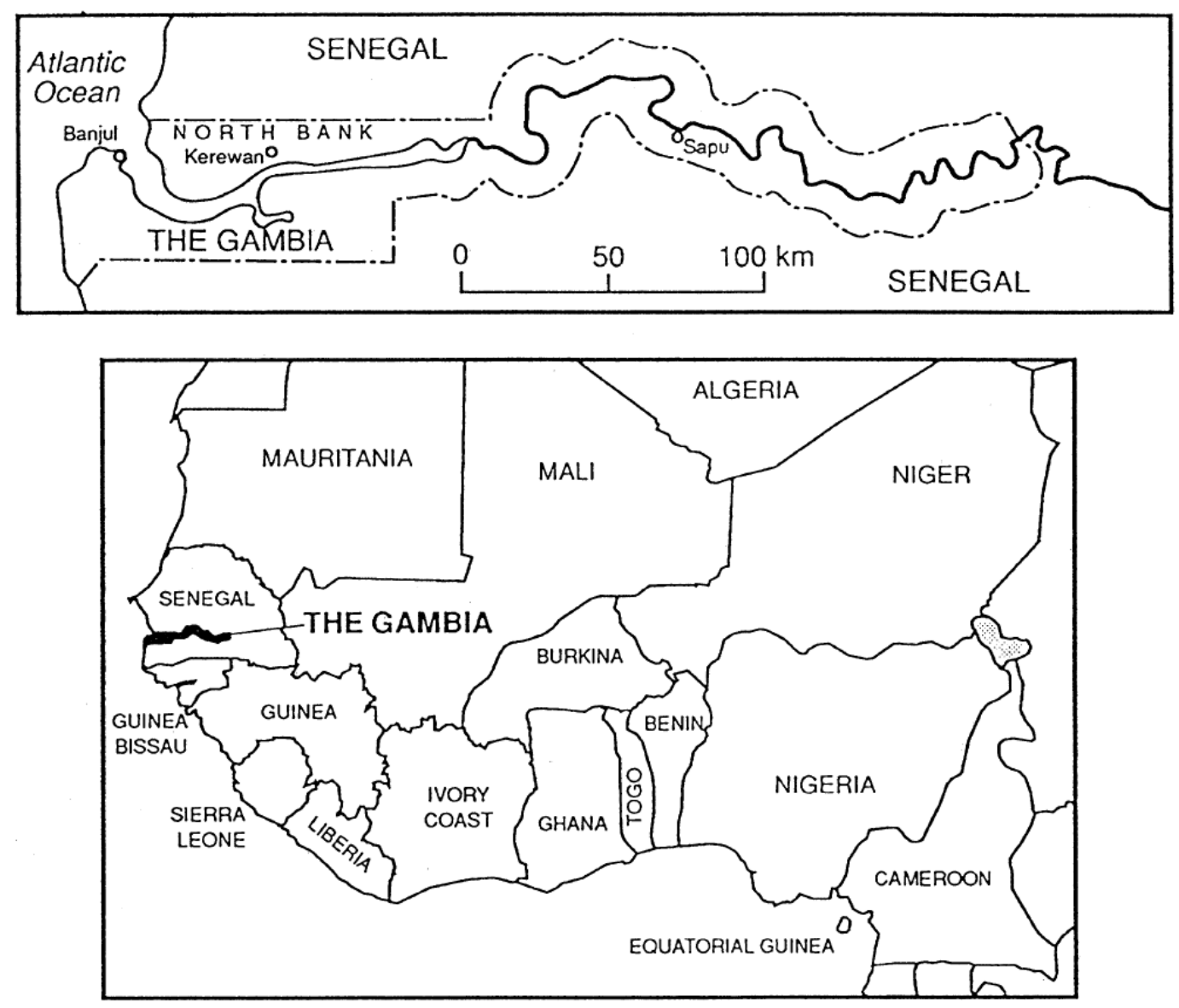

Figure 1: The Gambia

While The Gambia abounds in lowland swamps, not all are suitable for farming. Riverine swamps coming under marine tidal influence are permanently saline within 70 kilometers (42 miles) of the coast, seasonally saline up to 250 kilometers (150 miles), and fresh year-round only in the last 150 kilometers (90 miles) of the Gambia River's course (Carney, 1986, 33). The suitability of inland swamps for crop production, moreover, depends on the influence of differing moisture regimes for groundwater reserves. Consequently, although The Gambia contains over 100,000 hectares $(247,000$ acres) of lowland swamps, only about a third can be reliably planted (ALIC, 1981, 19; GGFP, 1984; CRED, 1985, 127). Until the mid-1980s most of the available swampland was farmed to rice, with about 20,000-25,000 hectares $(49,400$ 61,750 acres) planted along the river floodplain and another 6,000-8,000 hectares 
(14,800-19,760 acres) cultivated in inland swamps (FAO, 1983, 17; Government of The Gambia, 1973-91).

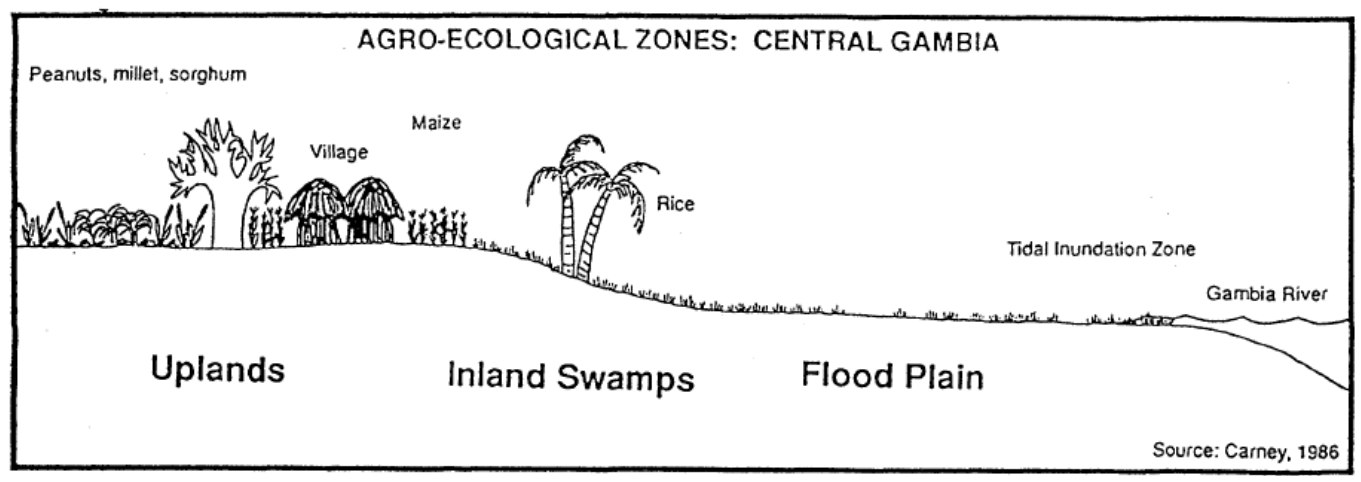

Figure 2: Agro-Ecological Zones: Central

Lowland cultivation is thus pivotal to the Gambian farming system, enabling crop diversification over a variety of microenvironments and a reduction in subsistence risk during dry climatic cycles. Wetland farming, however, requires considerable attention to forms of water availability as well as edaphic and topographic conditions. In The Gambia this knowledge is embodied in women, who have specialized in wetland cultivation since at least the early eighteenth century and have adapted hundreds of rice varieties to specific microenvironmental conditions (Jobson, 1623, 9; Gamble, 1955, 27; Carney, 1991, 40) This cumulative [local] knowledge of lowland farming underlies The Gambia's regional importance as a secondary center of domestication of the indigenous West African rice, Oryza glaberrima, cultivated in the area for at least three thousand years (Porteres, 1970, 47).

\section{Gender, Environment, and Economy: A Historical Overview}

Although lowland swamps and rice production are traditionally women's domain, prior to the mid-nineteenth century men and women were involved in both upland and lowland cropping systems through a division of labor based upon various agricultural tasks. Men assisted in field clearing for rice cultivation while women weeded upland cereal plots (Weil, 1982, 45-46; Carney and Watts, 1991, 657). The abolition of slavery and the turn to "legitimate commerce" led to Gambia's incorporation into the world economy through commodity production. By the 1830s peanut cultivation was proliferating on the uplands (Carney, 1986, 77-78). The imposition of British colonial rule by the end of the nineteenth century brought taxation and fiscal policies that accelerated reliance on peanuts as a cash crop, resulted in an increasingly specialized use of agricultural space, and led to a more gendered division of labor. These changes became most evident among the rice-growing Mandinka, Gambia's dominant ethnic group and principal wetland farmers. 
By the end of the century, Mandinka men's growing emphasis on peanut cultivation resulted in a reduction in millet and sorghum production for household subsistence (Weil, 1973, 23; Jeng, 1978, 123-24; Carney, 1986, 92). As women compensated for upland cereal shortfalls by augmenting rice production in lowland swamps, the gender division of labor became increasingly spatially segregated, with the cash crop concentrated on the uplands under male control and women's farm work largely oriented to lowland rice, which emerged as the dietary staple (Carney, 1986, 89-91) (Fig. 2). The specialized use of agricultural land and concomitant disruptions in the gender division of labor accompanying nineteenth-century commodity production provide the setting for understanding twentieth-century gender conflicts among the Mandinka over commodification of the Gambian wetlands.

Policy interest in wetland environments began in the early decades of the twentieth century, when colonial officials began documenting farming practices in diverse lowland settings (Carney 1986, 126-27). The objective was to improve household subsistence security and generate rice surpluses that would feed an expanding pool of migrant laborers, whose seasonal influx accounted for the pace of peanut expansion on the uplands ${ }^{3}$. Initial efforts focused on improving swamp accessibility by tree clearing and causeway and footbridge construction and on increasing yields through improved seeds. By the 1960s, swamp development projects had culminated in an expansion of rice planting to some 26,000 hectares $(65,000$ acres) (Carney, 1986, 178). But limits had been reached on the degree to which women could carry the subsistence burden. Further gains in food availability rested on altering the gender division of labor by drawing men into rice growing. The colonial government's inability to persuade Mandinka men to take an active part in rice cultivation brought swamp rice development to a close (Carney, 1986, 139; Carney and Watts, 1991, 660).

In 1949 the colonial government initiated another approach to surplus rice generation by implementing a large-scale irrigation scheme on the site of the presentday Jahaly Pacharr project. The Colonial Development Corporation (CDC) scheme departed from the earlier swamp rice improvement project in one important way: land was removed from female rice growers through a 30-year lease program (Carney, 1986, 126; Carney and Watts, 1991, 666). The project failed due to a poorly designed irrigation system and lack of male or female interest in wage work; yet the CDC scheme is notable for adumbrating the post-independence emphasis on irrigation as well as the gender-based conflicts that would surface in subsequent wetland development projects.

These conflicts center on the invocation of customary tenure "laws" by male household heads and village elites to reduce women's land and labor rights in rice

${ }^{3}$ Migrant laborers in peanut cultivation, known in The Gambia as "strange farmers," produced nearly half the peanut crop. They numbered nearly 20,000 in the interwar period and accounted for 1 out of every 20 rural residents (Carney, 1986, 121). 
farming or, in Mandinka nomenclature, the conversion of land with individual use rights (kamanyango) to land whose product is controlled by the household head (maruo). When colonial development policies during the 1940s improved swampland access and productivity, male household heads and village elites called into question women's customary use rights. In one case that reached the colonial authorities, Mandinka men argued that "if women mark the land and divide it, it would become 'women's property' so that when a husband dies or divorces his wife, the wife will still retain the land, which is wrong. Women must not own land" (Rahman, 1949, 1). Women's land access was clearly being contested by male claims that female use rights would alienate swampland from the residence unit. A similar conflict arose with the CDC project failure: women claimed use rights to the plots they farmed (kamanyango), and household heads declared the improved area as maruo land, whose product comes under male jurisdiction (Dey, 1980, 252-53). The significance of the maruo designation for resource struggles is that when it is applied females experience an erosion of their customary labor rights without a reduction in their work burden.

A brief review of the meaning of the two Mandinka terms for property access and use of resources illuminates the issues in dispute. Land in rural Gambia is held in communal tenure but carries several forms of property relations. On a general level, the household landholding is termed maruo and cannot be alienated from the residence group. But maruo additionally refers to a set of labor obligations and crop rights. All able family members are expected by custom to provide labor on household land for family reproduction. Men's maruo work responsibility is traditionally met on the uplands through cultivation of millet, sorghum and maize, or groundnuts, which may be traded to purchase cereals. Rice production traditionally fulfills Mandinka women's maruo obligations. Because maruo crops are produced for household subsistence, they come under control of the male household head, who arranges their distribution.

A second, and important, subset of tenure relations also operates on part of the family landholding. In exchange for providing labor toward household subsistence, junior males and all adult females are given access to some of the family's landholding for their own needs. These land rights and plots are known as kamanyango. As long as the farmer remains a member of the household she or he controls the plot's use and benefits from plot output. Kamanyango labor rights provide subordinate family members the means to obtain cash from farming, as they control the rights to the crop produced as well as decisions over its use. Kamanyango plots are a critical issue in Gambia, where rural society is largely polygynous, male and female budgets are frequently separate, and women traditionally are responsible for purchases of clothing and supplemental foods crucial for the well-being of their children.

The expansion of peanut commodity production during the nineteenth and early twentieth centuries, which shifted food cropping increasingly to wetland environments, resulted in a greater concentration of rain-fed land use into de facto kamanyango plots, whether or not it was so termed by male household heads. The reverse process accompanied commodification of lowland environments farmed to rice by women. As 
colonial rice development projects opened new areas for cultivation, women's kamanyango rights were repeatedly contested by male household heads, who placed them instead in the category of maruo. By claiming developed rice land as maruo, men placed the burden of subsistence responsibility on females, thereby liberating themselves from customary obligations. As women shouldered an ever greater work burden, male responsibility toward subsistence - either through cereal cultivation or purchase from groundnut earnings - diminished (Weil, 1973, 23) ${ }^{4}$. Women's preexisting labor rights steadily eroded in post-independence irrigation schemes, but with the strikingly different outcome that rural women mobilized to improve their deteriorating situation.

\section{The Environmental and Economic Crisis: Policy Shifts}

In the 28 years since independence, in 1965, The Gambia has experienced rainfall declines and accelerated environmental degradation of its uplands, a massive influx of foreign aid for development assistance (1968-88), policy shifts favoring commodification of the wetlands, and an International Monetary Fund (IMF) structural adjustment program (1985-present). These changes have shaped post-independence accumulation strategies and the gender conflicts among rural households.

Gambia entered independence with a degraded upland resource base and a vulnerable economy. The results of the long-standing monocrop export economy were evident throughout the traditional peanut basin, once mantled with forest cover but substantially deforested during the colonial period (Park, 1983, 4; Mann, 1987, 85). Reliance on one primary commodity, peanuts, to finance mounting rice imports grew more precarious in the years after independence; peanut export values fluctuated considerably from year to year, but through the 1980s grew less rapidly than the value of food imports (FAO, 1983, 4; Carney, 1986, 254). Farmers responded to declining peanut revenues through an intensification of land use - namely, by reducing fallow periods in peanut cultivation or by eliminating them altogether. The result was accelerated land degradation, particularly in the North Bank region, which was oriented to Senegalese peanut markets with generally higher producer prices (Fig. 1) ${ }^{5}$. Today the North Bank is stripped of forest cover, fallows have been reduced, and land degradation is more advanced than in the rest of the nation (Government of The Gambia, 1977; GGFP, 1988).

${ }^{4}$ Male maruo subsistence requirements frequently involved the purchase of kamanyango rice from their wives.

${ }^{5}$ The higher French support price for peanuts during the colonial period has generally prevailed in the independence period. 
Precipitation declines and environmental degradation of the uplands brought renewed attention to the wetlands. The 1968-73 Sahelian Drought coincided with an escalation of capital flows from multilateral banks and financial institutions to the Third World (Thrift, 1986, 16; Shiva, 1989, 220). The changing pattern of global capital accumulation impacted the Gambian wetlands in the form of river basin development and irrigated farming ${ }^{6}$.

International development assistance brought far-reaching changes to the critical wetland food production zone. Nearly 4,500 hectares (11,115 acres) of riverine swamps were converted to irrigation schemes and another 1,000 hectares $(2,470$ acres) of inland swamps to horticultural projects (Carney, 1992, 77-78). Although affecting less than 10 percent of total swamp land, these conversions in land use have had profound consequences for food production, female labor patterns, and access to environmental resources ${ }^{7}$. The irrigated rice schemes and the introduction of technology to implement year-round cultivation have not reversed the country's reliance on imported rice. Only 40 percent of the land under this new strategy of development remains in production, with just 10 percent under double-cropping (Carney, 1986, 278). As domestic production lags, milled rice imports steadily climb, currently accounting for more than half the country's needs (Government of The Gambia, 1991). Population growth rates exceeding 3 percent per annum suggest demographic pressure on agricultural land; yet the failure to achieve food security is not the result of a Malthusian specter. Rather, it is the outcome of the changing use and access to resources which concentrates land within the communal tenure system and denies women benefits from improved rice production.

By the 1980s, women's mounting economic marginalization from irrigated rice development resulted in nongovernmental organizations (NGOs) targeting them for horticultural projects developed on inland swamps. The policy emphasis on horticulture intensified with the debt crisis of the 1980s and the implementation of an IMF-mandated structural adjustment program in 1985 to improve foreign exchange earnings and debt repayment. Economic restructuring has reaffirmed The Gambia's comparative advantage in peanuts while favoring the conversion of hydromorphic swamps to horticulture (UNCTAD, 1986; Government of The Gambia, 1987; Landell Mills Associates, 1989; Harvey, 1990, 3; McPherson and Posner, 1991, 6).

${ }^{6}$ Among the institutions created during this period of unprecedented foreign investment in the Sahel was the Gambia River Basin Development Organization (OMVG). A regional development organization formed of four nations sharing the Gambia River watershed (Senegal, The Gambia, Guinea, and Guinea Bissau), the OMVG solicited funds for an expansion of irrigated farming, but never realized its objective of dam construction along the Gambia River.

${ }^{7}$ In addition to increasing the number of days annually spent in agriculture, irrigated rice projects greatly augmented seasonal labor demands by nearly tripling (232 to 650) the adult days spent in rice cultivation per hectare (Carney, fieldwork data). 
The respective policy emphases of the past 20 years have commodified the wetlands and incurred changes in customary use and access to environmental resources. As the irrigation schemes provide new avenues for income generation within rural communities, women's access to improved land for income benefits is increasingly being contested. The next two sections present an overview of the two post-drought wetland policy shifts, illustrating how customary laws are being reinterpreted to reduce women's access to productive resources and the forms of their resistance to such changes.

\section{"Drought-Proofing" the Economy: Irrigated Rice Development}

In 1966, one year after independence from Britain, the Gambian government, with bilateral assistance from Taiwan, initiated a wetland development strategy - the conversion of tidal floodplains to irrigated rice projects. It was to receive increasing donor emphasis following the 1968-73 Sahelian drought. The rationale for this development was to promote import substitution by encouraging domestic rice production. Rice imports had reached 9,000 tons per annum, and foreign exchange reserves had seriously eroded with declining world commodity prices for peanuts. The 1968-73 Sahelian drought revived the late colonial interest in irrigation and mobilized foreign aid for investment in river basin development and irrigated agriculture (UNDP, 1977; CILSS, 1979; Franke and Chasin, 1980, 148-51; Derman, 1984; CRED, 1985, 17). Hailed as a way of buffering the agricultural system from recurrences of a similar disaster, irrigation projects also created a steady demand for imported technical assistance, machinery, spare parts, and inputs. The "drought-proofing" strategy embodied in Gambian irrigation schemes targeted rice, whose import-substitution was prioritized by the post-independence government (Government of The Gambia, 1966; CRED 1985, 22). From the 1970s to the mid-1980s the World Bank, the mainland Chinese government, and the International Fund for Agricultural Development (IFAD) continued the Taiwanese development strategy by implementing double-cropped irrigated rice schemes on more than 4,000 hectares $(9,880$ acres) of women's tidal swamps (Fig. 3).

Despite the contrasting ideological perspectives of the donors involved, all development strategies adhered to a remarkably similar course by introducing the Green Revolution package for increased production to male household heads (Dey, $1981,109)$. Developed at a cost of U.S. $\$ 10,000$ to $\$ 25,000$ per hectare and inserted into a preexisting gendered form of agricultural production and land use, these schemes failed to deliver their technological promise and added to a growing dependence on imported inputs and spare parts (CRED, 1985, 273; Carney, 1986, 275). Donor production targets required double-cropping and thus a shift in agricultural production to year-round farming. Although male heads of households were taught this new form of production, cropping calendars could only be followed if women joined their husbands in irrigated rice farming. By placing men in charge of technologically improved rice production, the donors hoped to encourage male 
participation; instead, they unwittingly legitimized male control over the surpluses gained from double-cropping.

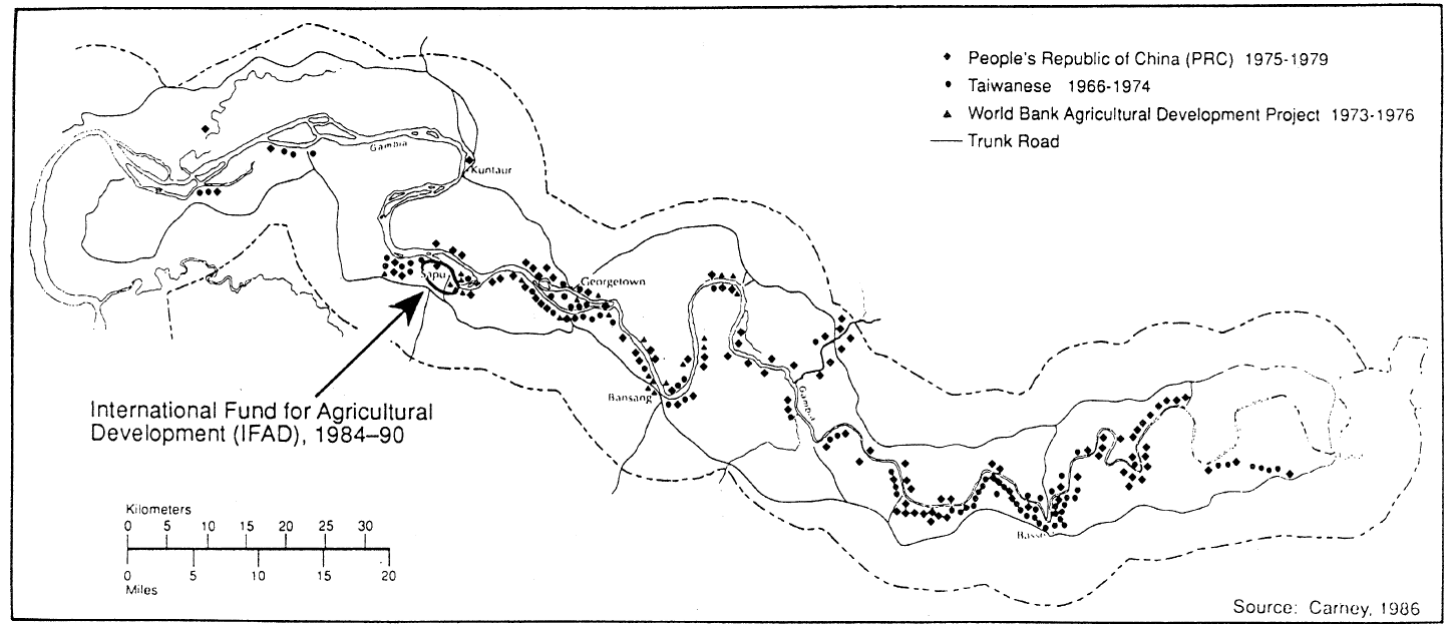

Figure 3: Irrigated Rice Projects in The Gambia

Control over the disposition of marketable surpluses proved pivotal to the gender-based conflicts that erupted within project households over which family members were to assume the increased work load. Male household heads claimed female labor under the customary category, maruo, but irrigated rice farming meant that the claim was invoked for year-round labor. As maruo labor claims for household subsistence had historically evolved within the confines of a single agricultural season, there was no precedent for women to perform labor obligations during two cropping periods when production would yield men a marketable surplus (Carney, 1988, 34142). Irrigation projects were commodifying rice production, but income gains depended on female labor availability.

Women contested the changing lexicon of plot tenure and the enclosure of traditional kamanyango and maruo swamp into irrigation schemes. "Development" meant the delivery of female labor for intensified rice farming without concomitant income gains. The reinterpretation of customary tenure by male household heads and village elites aimed to ensure continued female access to rice land, but only as workers on plots whose benefits would flow to men as disposable surpluses. The donors' uniformed view of the Gambian household-based production system was to prove the projects' nemesis.

Female rice farmers responded in three principal ways to loss of control over productive swampland and efforts to augment their labor burden: (1) by relocating kamanyango production to unimproved swamplands where they could generate small surpluses for sale; (2) when alternative swampland for rice farming was not available, 
by agreeing to perform maruo labor obligations on irrigated rice plots during the dryseason cropping cycle in exchange for using the same plot without irrigation during the rainy season for kamanyango production; or (3) by laboring year-round on irrigated schemes but demanding remuneration in rice for their labor during one cropping season (Carney, 1994). All but the first response involved a substantial increase in women's labor. The third pattern represented an even more pronounced departure in female access to resources as kamanyango land rights in rice production came to an end and female labor was converted into wage work.

The first two responses characterized the earliest phase of irrigated rice development implemented in a small scale on community perimeters (ca. 30 hectares, or 74 acres). The third response was developed in 1984 with the 1,500 hectare $(3,705$ acres) IFAD-funded Jahaly Pacharr irrigation scheme, which incorporated most of the available swampland of 40 contiguous villages and proletarianized numerous women from floodplain rice cultivation. Seeking to ensure compliance with the year-round cropping calendar and production targets, the IFAD project had implemented an additional mechanism reminiscent of the earlier colonial CDC project. Community control over project land use terminated with a 30-year lease, which placed the irrigated swampland under project jurisdiction. The lease permitted the state to tie plot use to repayment of the credited inputs and mechanization charges; these rates, in turn, were based on anticipated productivities (IFAD 1988). Households unable to comply with these terms faced eviction.

The project's mandate to double-crop as a condition for participation placed intense pressure on household labor, which plot designation as maruo could not easily resolve. Previous irrigation schemes had frequently accommodated women's kamanyango claims at the cost of year-round pumped production. Confronted by a legal mechanism that threatened eviction for households falling short of production targets, women now faced enormous pressure within the household to augment their labor burden. Because project development had incorporated most of the region's available swampland, preexisting kamanyango land access came to an end. Genderbased conflicts exploded throughout the project area as women resisted the erosion of their right to derive benefits from a greatly augmented work burden and sought to reconstitute the rights embraced by kamanyango in other ways. While ethnicity, class, and differences among types of irrigated cultivation available within the project shaped the ensuing patterns of conflict resolution, the third response to loss of land access dominated among Mandinka women (Carney, 1994) ${ }^{8}$. Nonetheless, many households failed to honor women's demand for access to project land for kamanyango cultivation

${ }^{8}$ The IFAD project had also improved some swamps that relied on river tides for irrigation. In several Mandinka communities this land was given to women for kamanyango production. But the tidal irrigated area was of limited areal extent and not available to most of the project's women (Carney, 1988, 1994). 
or remuneration in kind for year-round maruo labor, resulting in women's outright refusal to work on the family's irrigated plots.

These dispossessed women consequently pursued two complementary economic strategies for income generation: the formation of work groups to carry out the project's labor-demanding tasks of transplanting, weeding, and harvesting; and a shift in kamanyango production to upland cultivation. By organizing work groups for hire, women have managed to bid up their daily wage rate within the project and to take advantage of peanut land made available as men intensified their work in the more remunerative rice scheme (Webb, 1989, 66). But their efforts to obtain upland kamanyango plots were not always successful as they came into direct competition with the claims of junior males for individual land rights. Women have consequently placed considerable effort into gaining the support of nongovernmental organizations to develop village vegetable gardens for income generation (Carney, 1986, 311).

In summary, wetland development policy unfolded initially on riverine floodplains. As these areas became technologically improved and commodified, male household heads reinterpreted women's preexisting crop rights and benefits to gain access to their labor for the intensified work burden. Irrigated rice development simultaneously undermined women's customary access to rice land for income generation, while enabling male household heads to capture surplus value. By rupturing the relationship between women's knowledge systems, agronomic expertise, and rice farming, project households are beset with repeated delays in cropping schedules as well as an inability to follow agronomic recommendations. By the 1990s the legacy included poor rates of double-cropping, declining productivities, and failure to achieve rice import-substitution.

Like its predecessors, the much-heralded IFAD project now operates principally during the dry season. IMF reforms, which raised the producer price of peanuts relative to rice, have resulted in males shifting labor to peanuts during the wet season. Yet despite the project's failure to generate reserves of surplus rice, few households have faced eviction. The Jahaly Pacharr project has become politically sensitive throughout rural Gambia as an example of the state's attempt to "take" land from peasants (Carney, 1991, fieldwork).

Notwithstanding repeated state-peasant and male-female conflicts over rice land, irrigated development remains a governmental priority. Gambian political officials and their foreign advisors are currently reviewing ways to more efficiently restructure the irrigation sector. Alternative cropping arrangements in irrigated farming are being explored whereby farmers more "modern" in outlook may be asked to contract irrigated land (Carney, 1994). As policy measures increasingly dictate debt repayment and comparative advantage, the earlier small-scale schemes are being rationalized into larger units for centralized pumping and management (CILSS, 1990). A mounting emphasis is being placed upon crops, like fruits and vegetables, that generate foreign exchange. By 1991 even the plot bunds of Jahaly Pacharr's rice fields were being planted with bananas. 
During the 1980s, the international development assistance community challenged male control over irrigation schemes by funding women's horticultural projects on unimproved inland swamps previously sown to rice. The explicit "women in development" focus of NGOs and multilateral donors aimed to bolster female income-earning opportunities by improving seasonally wet swamps, with wells for dry-season planting. As cropping patterns shifted to export production, the process of commodification was brought to inland swamps, with contradictory implications for women.

\section{Comparative Advantage and Horticultural Development}

Shortly after the 1968-73 Sahelian drought the Gambian government promoted economic ventures in inland swamps that grew over the years into a major focus of donor assistance and income generation within the country. During the 1970s, the government encouraged onion-growing schemes among village women's groups as a means to increase household incomes in the peri-urban corridor and North Bank district, geographically proximate to the capital (Ceesay et al., 1982) (Fig. 1). During the next decade women's vegetable gardens emerged as a major focus of donor support within the country. By the 1990s over 340 small- (0.5-2 hectares, or 1.1-4.9 acres) and medium-scale (5-15 hectares, or 12.3-37 acres) vegetable gardens were developed by NGOs and multilateral donors (Smith, et al., 1985; Nath, 1985; Sumberg and Okali, 1987; Giffen, 1987; DeCosse and Camara, 1990). The entry of private growers into the burgeoning horticultural sector, along with incipient women vegetable growers' groups (not funded), accounts for an expansion of market gardening that currently exceeds 1,000 hectares (2,470 acres) (Carney, 1992, 79).

The boom in market gardening on Gambian wetlands results from the confluence of several policy directions during the past 15 years. Following independence, Gambia began developing its pristine beaches for international tourism; by the 1990s over 100,000 Europeans were taking a six-hour flight to vacation along the Gambian coast between November and April (N'Jang, 1990). The initial onion projects successfully linked local production to the tourist sector and awakened donor agencies to the possibilities of expanding vegetable production for the dry-season tourist demand. These developments, meanwhile, were unfolding against a growing clamor within the international donor community for women in development (WID) projects. The emergent WID focus in The Gambia was pioneered by NGOs that viewed vegetables, traditionally planted by Gambian females, as the solution to women's limited economic opportunities.

Policy support for diversifying wetland agriculture into horticulture received additional impetus in 1085 with an IMF-mandated structural adjustment program. Geographic proximity to Europe encouraged policymakers to exploit The Gambia's comparative advantage as a winter fruit and vegetable supplier, as did favorable tariffs and the removal of export taxes on fresh produce (UNCTAD, 1986; Government of 
The Gambia, 1987; Jack, 1990). Seeds of nontraditional horticultural crops such as lettuce, tomatoes, green peppers, carrots, eggplants, beans, cabbages, and tropical fruits were distributed, and marketing strategies focused on hotels, the expatriate community, neighboring Senegal, and Europe.

By the 1990s horticultural production had expanded to rainfed areas in the periurban corridor located near the international airport, with boreholes dug to reach underground aquifers. With few exceptions, the projects are operated by the state, senior government officials, and resident Lebanese and Indian landowners and are oriented to European export markets. In the five years following IMF economic reforms, annual fruit and vegetable exports to Europe alone grew to 3,000 tons, a value exceeding U.S. \$1 million (Jack, 1990). The same period witnessed the growing involvement of multilateral donors (European Economic Community, Islamic Development Bank, United Nations Development Program, and the World Bank) in women's horticultural production and marketing along the coastal corridor (Ceesay, et al., 1982; Government of The Gambia, 1987; Barrett and Browne, 1991, 244; Carney, 1992, 78; World Bank, 1990). Despite this most recent form of donor support, Gambian women's horticultural projects remain concentrated in rural areas, on inland swamps of small areal extent (0.5-2 hectares, or 1.2-4.9 acres), and oriented to local and regional markets.

Although the policy emphasis on converting inland swamps to horticulture dates from the 1970s, Gambian women have long been involved in vegetable production. They were observed marketing vegetables during the dry season as far back as the mid-fifteenth century, while eighteenth-century travelers noticed vegetable cultivation in inland swamps following the rice harvest (Adanson, 1759; Crone, 1937, 48; Park, 1983). Dry-season horticultural production received encouragement during the colonial period, but its expansion was limited by the elementary technology employed for irrigation, shadufs, in which river water is lifted by hand for watering (Carney, 1986, 144). Although colonial horticultural programs targeted men, their failure left vegetable growing in women's hands. Females remained the country's principal producers, using residual moisture from inland rice swamps early in the dry season to cultivate traditional crops such as bitter tomatoes, okra, sorrel, and hibiscus for subsistence.

Donor support for well construction from the 1980s has enabled an extension of the vegetable-growing period in inland swamps. Deeply dug, concrete-lined wells have revolutionized Gambian horticultural production by tapping water tables for dryseason cultivation. Vegetable gardening is no longer a seasonal activity, as it was prior to donor involvement. Women's village gardens receiving NGO assistance grow vegetables during the entire dry season and, in some cases, year-round.

The provision of reliable water supplies through well-digging is central to NGO efforts to implement a rural development strategy aimed at improving women's incomes. By promoting village gardens for women's groups interested in commercialized vegetable cultivation, NGOs have launched a development strategy 
that targets women who were ignored in the previous wetland policy approach. NGO support for well construction has proved crucial to women's negotiations with male landowners and village elites for access to land for communal vegetable gardens. At a cost of U.S. $\$ 3,000-4,000$ per hectare, these wells provide communities a valuable infrastructure to ensure a permanent water source for dry-season agricultural production (Nath, 1985, 6; Sumberg and Okali, 1987; Schroeder, 1989, 13).

Arrangements to secure female access to improved village gardens, however, vary between communities and depend on the availability of land locally, as well as the swamp's land use history. Consequently, in rural communities with NGO-supported gardens, women are granted either year-round usufruct for cash-cropping vegetables or kamanyango dry-season rights, with the plot reverting to subsistence cereal production in the rainy season. Once access to land is accomplished, NGOs provide assistance for constructing concrete-lined wells and barbed wire fences (for protection from livestock damage). When completed, female growers are credited the seeds and tools for vegetable farming.

A labor-intensive process, vegetable gardening during the dry season requires two daily waterings - averaging about two hours per session - weeding, and pest control, as well as transporting the bulky and highly perishable produce to weekly markets. But in a country where rural per capita income averages U.S. \$130, efforts are often rewarded (World Bank, 1981). Schroeder $(1992,4)$ records that women vegetable growers in surveyed North Bank villages gross incomes ranging between U.S. \$67-265 during the dry season, with more than half of them reporting incomes exceeding their husbands' earnings from peanuts. These income differentials are the new source of contemporary gender conflict in North Bank vegetable gardens.

An examination of three areas where market gardens figure prominently in women's economic options reveals the effects of improved water availability and increased income opportunities in fueling contemporary gender conflicts. These include: (1) the area around Kerewan on the North Bank, site of the pilot onion schemes, which borders neighboring Senegal; (2) across the Gambia River, the periurban corridor close to the capital, Banjul, where tourist hotels, government offices, and the expatriate community are concentrated; and (3) 260 kilometers (156 miles) upriver from the capital on the river's south bank, the IFAD-funded Jahaly Pacharr project, centered at Sapu. The first two areas, the original loci for horticultural development, enjoy numerous marketing opportunities, while women growers in the IFAD project rely solely on weekly markets (lumos) for vegetable sales. While income returns from vegetable marketing in the peri-urban corridor approximate the low range cited for North Bank growers, incomes in the IFAD project are only U.S. \$15-35 for dry-season production (Carney, 1991, fieldwork).

Each of these areas offers men different income opportunities. Jobs in government, the tourist sector, petty commerce, and transportation are concentrated in the capital. In the IFAD project and North Bank areas, men derive their income chiefly from agriculture - peanuts and irrigated rice in the former, peanuts in the latter. As 
noted above, within the IFAD project men's control over irrigation schemes and peanut farmland has severely limited women's access to village land for vegetable gardens. The explosion during the past five years of banana cultivation by men within the IFAD project, directly along the banks of riverine tributaries, and in inland swamps outside the project area has reduced wetland availability even further ${ }^{9}$. Village women in the IFAD scheme accordingly have severely restricted access to potential garden land; when they do manage to negotiate land access, it is usually only for dry-season vegetable cultivation.

Female growers in the capital face an altogether different situation. The concentration of tourist hotels, an expatriate community, and international horticultural trade provide them numerous marketing opportunities. But potential income benefits are limited by the proliferation of vegetable projects and the excessive number of female participants in each scheme. Local markets are saturated with women selling vegetables, resulting in meager returns for their labor and a continuous search for new outlets. An important outcome of the explosion of vegetable gardens within the periurban corridor is the growing involvement of women's groups in contract farming production relations with large growers. While the latter arrangement provides an outlet for excess production, produce prices are driven down by large-scale growers and traders, who set prices and control distribution networks (Carney, 1992, 80-82).

Vegetable gardening nonetheless remains attractive to women, whose alternative income-earning prospects are limited. While structural adjustment programs have led to a 10 percent reduction in employment within the government sector and have catapulted men into increasing involvement in horticultural production, women have generally maintained usufruct to village land for gardening because donor representatives, located in the capital, are poised to defend them. The case of the North Bank, detailed by Schroeder (1993) differs, however, and provides yet another illustration of the complex intersection of gender with environmental transformation and economic change.

Proximity to the land border with Senegal and declining peanut production associated with upland environmental degradation underlie the gender conflicts that have emerged in North Bank horticultural projects. As with peanuts, most vegetable production flows across the border to Senegal, where horticultural import-export distribution networks are of operator antiquity, internal demand for vegetables is more developed, and prices are higher (Mackintosh, 1989, 15). NGO improvement of inland swamps with wells has resulted in new avenues for income generation that sharply conflict with the WID objectives of NGOs.

${ }^{9}$ The explosion in banana cultivation along the main river bank led to deforestation of a threemile stretch of primary riparian forest by 1991 (Carney, 1991, fieldwork). 
NGO-funded vegetable projects in North Bank communities have transformed the inland swamps and the social relations regulating preexisting cropping and labor patterns. Well construction, in effect, has widened the seasonal window that formerly regulated vegetable cultivation. Crops are no longer confined to the autumnal planting period following the rice harvest; vegetables can be planted throughout the dry season, and frequently year-round, since profits from cross-border sales currently compensate for displaced rice production (Schroeder and Watts, 1991, 62).

As North Bank horticultural projects have considerably augmented women's earnings, female rights of disposal over their income and access to vegetable land have come under increasing threat. Schroeder (1993) reports men deferring to women the burden for costs formerly met by males and their capture of part of women's earnings through unpaid loans. Additionally, male landholders in numerous communities are contesting women's access rights to vegetable land through the planting of economically valuable trees (e.g. mango and orange) within the vegetable gardens. After five to ten years the canopy closes, blocking the sunlight needed for vegetable growth. Tree planting therefore facilitates the conversion of land use from vegetable gardens to orchards, enabling male landlords to reclaim the improved plots for their own economic strategy based on tree crops within a decade (Schroeder, 1992, 9).

By making verbal agreements with NGOs for women's vegetable gardens, landlords are acquiescing to female demands for kamanyango land rights. But these rights are honored only for a limited number of years - those required to capture women's labor for watering adjacent fruit trees during the initial growth period. The use of economically valuable trees to recapture garden plots as male kamanyango over the long run, however, is not lost on women. Schroeder (1993) notes the gender confrontations that have occurred with orchard planting: women cutting back mango and orange trees as they begin shading out vegetables, deliberately setting fires to fatally damage fruit trees, and sending delegations to local officials for legal action.

The inland swamps of the North Bank, formerly used by women for subsistence rice production, are being increasingly commercialized to vegetables. But the process is unfolding within a region of limited economic opportunity and severe environmental degradation. While NGOs attempted to address the gender equity issue ignored in the first wetland development phase, this second development approach indicates that women's gains over the long run are indeed precarious.

\section{Conclusion}

The structural dislocation of a monocrop export economy and attendant food shortages brought government attention to the Gambian wetlands during the late colonial period. The pattern of swamp development implemented during colonial rule foreshadowed the large-scale emphasis on the wetlands that materialized with the influx of foreign capital coincident with the Sahelian drought. During the past 25 years, wetland development through irrigation projects has transformed Gambian 
agriculture from a seasonal to a year-round activity, enabling agricultural diversification, surplus cereal production, and new avenues of income generation among rural households.

The promise of irrigated agriculture, however, depends upon the ability of peasant households to restructure family labor to the dictates of irrigated farming - a labor regime that requires a greater work burden during the entire calendar year. As claims to family labor evolved in the context of a limited wet season, institutional mechanisms within the household-based production system were deformed to mobilize family labor for year-round agriculture. Use of the term maruo, for technologically improved swamps, is central to obtaining a female labor reserve for the intensified work burden in irrigated farming. While reaffirming the integrity of the patriarchal family landholding, the naming of developed land, maruo, in practice facilitates men's claim to benefits produced by female labor.

Women contest the semantics of maruo precisely because this new meaning is a mechanism that deprives them of their customary rights. They are acutely aware that the rules of access to, and control over, environmental resources are not a codification of immemorial tradition, but rather the outcome of struggle and negotiation with husbands, male community leaders, state and donor officials (Berry, 1986, 5; OkothOgendo, 1989, 14). This awareness has sharpened in the past 25 years with irrigation projects that have imbued wetlands with new economic value. Gambian women are not engaging men in mere semantic discussion as they struggle for kamanyango rights their actions reveal growing recognition that commodification of the wetlands is steadily eroding their economic and social status within the household and village community.

The two case studies of irrigated agriculture illustrate the multiple ways in which women contest and renegotiate their access to resources. Struggles in rice schemes have centered on reaffirming claims to a portion of the surplus by requesting seasonal plot use as kamanyango; remuneration in the form of paddy rice for yearround labor availability; or, when labor benefits are denied, outright refusal to work on the household's irrigated fields and entry into local wage markets for improved rates of pay. Each outcome of women's struggles, however, has resulted in an intensification of female work burdens without commensurate income gains.

Women's fortunes appear much improved in vegetable projects, where females are granted kamanyango cropping rights seasonally or year-round. But female growers find their incomes from garden cultivation being claimed in new ways by their husbands, who, in some eases, refuse to pay back the loans given by their wives or abrogate their contributions toward household expenses (Schroeder, 1993). Moreover, the increasing emphasis on orchards for income generation indicates that women's kamanyango gardening rights may only be exercised for a limited number of years equivalent to the time required for hand-watering of trees until the plot's land use converts to mature orchards (Schroeder, 1993). Despite income gains and growing 
militancy, women's earnings in vegetable gardening appear precarious over the long run.

These case studies indicate that a process of land concentration is occurring in Gambian wetlands improved with irrigation. Concentration is not the result of absolute land scarcity and overpopulation but rather a response to household labor shortages and new income opportunities with irrigated agriculture. The designation, maruo, for irrigated land reveals how land is enclosed to create an artificial scarcity for accessing female labor. This unusual form of enclosure permits women access to irrigated land while denying them benefits from their work. Land concentration consequently involves the conversion of a developed plot from one with multiple female rights to the surplus product to land with a single claim over the surplus produced by multiple female laborers.

In contrast to the pattern described by Humphries (1990, 38-39) for eighteenthcentury England, land enclosure in The Gambia has resulted in very different outcomes for women. While land enclosures in England pushed rural men into waged work and left their wives and children to defend traditional rights to rural resources, it is women in contemporary rural Gambia who are increasingly proletarianized, as men gain control of both customary rights over female labor and the income from irrigated lands. The forms of economic change promoted by national and international organizations are intensifying household labor demands in wetland cultivation, thereby spearheading a form of enclosure that uses the maruo designation to weaken women's customary rights to rural resources so that male heads of households can capture their labor for individualized accumulation.

In outlining the social and historical processes of changing land use strategies on the Gambian wetlands, this paper reveals that more than the environment is being transformed. So too are the social relations that mediate access to, and use of, land within rural households. As commodification transforms the use of wetland environments, the social relations that produce these environments are also restructured (Berry, 1989, 41). The process of wetland conversion in The Gambia clearly illustrates these changes in women's reduced control over lowland use at the household level and in their frequent expulsion from technologically improved swamps. The contemporary pattern of accumulation unfolding in the Gambian wetlands centrally depends on controlling access to irrigated land by "freeing" women from their customary rights and by imposing new work routines that undervalue and intensify their labor contribution. Women, however, are resisting their newly assigned role as cheap labor reserves. Changing self-perception among women in rural Gambia has resulted in protests, household- and village-level negotiations that are modifying resource strategies and agrarian practices on the irrigated wetlands. 


\section{References}

Adanson, M. 1759. A Voyage to Senegal, the Isle of Goree and the River Gambia. London: Nourse.

Arid Lands Information Center (ALIC). 1981. Environmental Profile of The Gambia. Tucson: Office of Arid Lands Studies.

Barrett, H. and A. Browne, 1991. Environment and economic sustainability: Women's horticultural production in The Gambia. Geography 776, 241-48.

Bassett, T. 1988. The political ecology of peasant-herder conflicts in the northern Ivory Coast. Annals of the Association of American Geographers 78(3), 453-72.

Berry, S. 1989. Social institutions and access to resources. Africa 59(1), 41-55.

Berry, S. 1986. Concentration without privatisation: Agrarian consequences of rural land control in Africa. In, Conference on Agricultural Policy and African Food Security: Issues, Prospects and Constraints, Toward the Year 2000. ChampagneUrbana: Center for African Studies, University of Illinois.

Blaikie, P. and H. Brookfield (eds.). 1987. Land Degradation and Society. New York: Methuen.

Bryant, R. 1992. Political ecology: An emerging research agenda in Third World studies. Political Geography 11(1), 12-36.

Carney, J. 1994. Contracting a food staple in the Gambia. In, P.D. Little and M.J. Watts (eds.), Living under Contract: Contract Farming and Agrarian Transformation in Sub-Saharan Africa. Madison, University of Wisconsin Press, pp. 167-87.

Carney, J. 1992. Peasant women and economic transformation in The Gambia. Development and Change 23:67-90.

Carney, J. 1991. Indigenous soil and water management in Senegambian rice farming systems. Agriculture and Human Values 8, 37-58.

Carney, J. 1988. Struggles over crop rights within contract farming households in a Gambian irrigated rice project. Journal of Peasant Studies 15, 334-49.

Carney, J. 1986. The social history of Gambian rice production: An analysis of food security strategies. Ph.D. dissertaion, University of California, Berkeley.

Carney, J. and M. Watts. 1991. Disciplining women? Rice, mechanization, and the evolution of Mandinka gender relations in Senegambia. Signs 16, 651-81. 
Ceesay, M., O. Jammeh and I. Mitchell. 1982. Study of Vegetable and Fruit Marketing in The Gambia. Banjul, The Gambia: Ministry of Economic Planning and Industrial Development and the World Bank.

Center for Research on Economic Development (CRED). 1985. Rural Development in the Gambian River Basin. Ann Arbor: CRED.

CILSS (Permanent Interstate Committee for Drought Control in the Sahel). 1990. Study on Improvement of Irrigated Farming in The Gambia. Paris: Club du Sahel.

CILSS (Permanent Interstate Committee for Drought Control in the Sahel). 1979. Development of Irrigated Agriculture in Gambia: General Overview and Prospects. Proposals for a Second Program 1980-1985. Paris: Club du Sahel.

Crone, G. R. 1937. The Voyage of Cadamosto. London: The Hakluyt Society.

DeCosse, P. and E. Camara. 1990. A Profile of the Horticultural Production Sector in The Gambia. Banjul, The Gambia: Department of Planning and Ministry of Agriculture.

Derman, W. 1984. USAID in the Sahel. In, J. Barker (ed.), The Politics of Agriculture in Tropical Africa. Beverly Hills: Sage, pp. 77-97.

Dey, J. 1981. Gambian women: Unequal partners in rice development projects? Journal of Development Studies 17, 109-22.

Dey, J. 1980. Women and Rice in The Gambia: The Impact of Irrigated Rice Development Projects in the Farming System. Ph.D. dissertation, University of Reading.

Dunsmore, J. R. 1976. The Agricultural Development of The Gambia: An Agricultural, Environmental and Socio-economic Analysis. Land Resource Study no. 22. Surrey: Land Resources Division, Ministry of Overseas Development.

Food and Agriculture Organization (FAO). 1983. Rice Mission Report to The Gambia. Rome: FAO.

Franke, R. and Chasin, B. 1980. Seeds of Famine. Montclair, N. J.: Allanheld.

Gambia German Forestry Project (GGFP). 1988-91. Unpublished project data.

Gamble, D. 1955. Economic Conditions in Two Mandinka Villages: Kerewan and Keneba. London: Colonial Office.

Giffen, J. 1987. An Evaluation of Women's Vegetable Gardens. Banjul: Oxfam. 
Government of The Gambia. 1973-91. Sample Surveys of Agricultural Production.

Banjul: Public Planning and Monitoring Unit.

Government of The Gambia. 1987. Donors Conference on the Agricultural Sector in The Gambia. Banjul: Ministry of Agriculture.

Government of The Gambia. 1977. The Gambia: Land and Vegetation Degradation

Survey: The Need for Land Reclamation by Comprehensive Ecological Methods.

Banjul: Ministry of Agriculture.

Government of The Gambia. 1966. Five Year Plan for Economic and Social

Development. Banjul: Ministry of Economic Planning and Industrial

Development.

Hardin, G. 1968. The tragedy of the commons. Science 162,1243-48.

Harvey, C. 1990. Improvements in Farmer Welfare in The Gambia: Groundnut Price Subsidies and Alternatives. Institute of Development Studies (IDS) Discussion Paper no. 277. Sussex: IDS.

Humphries, J. 1990. Enclosures, common rights, and women: The proletarianization of families in the late eighteenth and early nineteenth centuries. The Journal of Economic History 2(1), 17-42.

Hutchinson, P. 1983. The Climate of The Gambia. Banjul: Ministry of Water Resources and the Environment.

International Fund for Agricultural Development (IFAD). 1988. Small-Scale Water Control Program. Rome: IFAD.

Jack, I. 1990. Export Constraints and Potentialities for Gambian Horticultural Produce.

Report prepared for the National Horticultural Policy Workshop. Banjul: Ministry of Agriculture.

Jeng, A. A. 1978. An Economic History of The Gambian Groundnut Industry 18301924. The Evolution of an Export Economy. Ph.D. dissertation, University of Birmingham.

Jobson, R. 1623\{1904\}. The Golden Trade. Devonshire: Speight and Walpole.

Landell \& Associates. 1989. A Market Survey for Gambian Horticultural Crops in the L7K, Sweden, The Netherlands and The Federal Republic of Germany. London: Commonwealth Secretariat.

Mackintosh, M. 1989. Gender, Class and Rural Transition. Atlantic Highlands, N.J.: Zed. 
Mcpherson, H. and J. Posner, J. 1991. Structural adjustment in sub-Saharan Africa: Lessons from The Gambia. Paper presented at the 11th Annual Symposium of the Association for Farming Systems Research-Extension, Michigan State University.

Mann, R. 1987. Development and the Sahel disaster: The case of The Gambia. The Ecologist 17, 244-90.

Nath, K. 1985. Women and Vegetable Gardens inThe Gambia. Action Aid and Rural Development. Working Papers no. 109, African Studies Center. Boston: Boston University Press.

N'Jang, A. 1990. Characteristics of Tourism in The Gambia. Banjul: Ministry of Information and Tourism.

Okoth-Ogendo, H. 1989. Some issues of theory in the study of tenure relations in Africa agriculture. Africa 59(1), 56-72.

Park, M. 1983[1799]. Travels into the Interior of Africa. London: Eland.

Porteres, R. 1970. Primary cradles of agriculture in the African continent. In, J. Fage and R. Oliver (eds.), Papers in African Prehistory. Cambridge: Cambridge University Press, pp. 43-58.

Rahman, A. K. 1949. Unpublished notes on land tenure in Genieri, courtesy of David Gamble. Satellites expose myth of marching Sahara. Science News, 23 July 1991, 38.

Schroeder, Richard A. 1993. Shady practice: gender and the political ecology of resource stabilization in Gambian garden/orchards. Economic Geography 69 (4), 349-56.

Schroeder, R. 1992. Shady Practice Gendered Tenure in The Gambia's Garden/Orchards. Yundum: Department of Agriculture Horticultural Unit and Oxfaln America.

Schroeder, R. 1989. Seasonality and Gender Conflict in Irrigated Agriculture: Mandinka

Rice and Vegetable Production in The Gambia. Co-evolutionary terrains: History, ecology and practice in Malagasy and Gambian rice systems, Working Paper no. 4. New York: Rockefeller Foundation.

Schroeder, R. and Watts, M. 1991. Struggling over strategies, fighting over food: Adjusting to food commercialization among Mandinka peasants. Research in Rural Sociology and Development 5, 45-72. 
Shiva, V. 1989. Staying Alive. Women, Ecology and Development. London: Zed.

Smith, F., I. Jack and R. Singh. 1985. The Survey of Rural Women's Vegetable Growing and Marketing Programme. Banjul: Action Aid.

Sumberg, J. and C. Okali. 1987. Workshop on NGO-Sponsored Vegetable Gardening Projects in The Gambia. Yundum: Department of Agriculture Horticultural Unit and Oxfam America.

Thrift, N. 1986. The geography of international economic disorder. In, R. J. Johnston and P. J. Taylor (eds.), A world in crisis? New York: Basil Blackwell, pp. 12-67.

United Natlons Commission on Trade and Development (UNCTAD). 1986. PostHarvest Handling and Quality Control for Export Development of Fresh Horticultural Produce (Gambia). Geneva: UNCTAD/GATT.

United Nations Development Program (UNDP).1977. Development of the Gambia River Basin. Multi-Disciplinary Mission and Multidonor Mission. Programme of Action. New York: UNDP.

Webb, P. 1989. Intrahousehold Decisionmaking and Resource Control: The Effects of Rice Commercialization in West Africa. Washing ton, D.C.: International Food Policy Research Institute (IFPRI).

Weil, P. 1982. Agrarian production, intensification and underdevelopment: Mandinka women of The Gambia in time perspective. In, Proceedings of the Title XI1 Conference on Women in Development. Newark: University of Delaware.

Weil, P. 1973. Wet rice, women, and adaptation in The Gambia. Rural Africana 19, 20-29.

World Bank. 1990. Women in Development Project: Staff Appraisal Report. Washington, D.C.: World Bank.

World Bank. 1981. The Gambia: Basic Needs in The Gambia. Washington, D.C.: World Bank.

Zimmerer, K. 1991. Wetland production and smallholder persistence: Agricultural change in a highland Peruvian region. Annals of the Association of American Geographers 81(3), 443-63 